\title{
Cephalopod Species Captured by Deep-water Exploratory Trawling in the Northeastern Ionian Sea
}

\author{
E. Lefkaditou and Ch. Mytilineou \\ National Centre for Marine Research, Aghios Kosmas, Hellinikon, 16604 Athens, Greece \\ P. Maiorano and G. D'Onghia \\ Department of Zoology, University of Bari, via E.Orabona 4, 70125 Bari, Italy
}

\begin{abstract}
The search for new fishing grounds in Greek waters, has led to the investigation of unexploited resources on the continental slope of the Northeastern Ionian Sea (Central Mediterranean Sea). Four seasonal experimental surveys were carried out by Greek and Italian commercial trawlers from September 1999 to September 2000, in the framework of the project called "Interregional environmental studies in the Ionian Sea". Potential targets included deep-water species of fishes, crustaceans and cephalopods.
\end{abstract}

During the 4 surveys, a total of 25 species of cephalopods belonging to 10 families were recorded, including 10 oegopsid squids, two myopsid squids, five octopods, two cuttlefishes and six sepiolids. Sepietta oweniana was the most abundant species, followed by Todaropsis eblanae, Illex coindetii and Loligo forbesi. Some uncommon species such as Ancistroteuthis lichtensteini, Ctenopteryx sicula and Galiteuthis armata, were recorded for the first time in the study area. An extension of the depth range was recorded for several species.

The results of multivariate analyses, based on Bray-Curtis similarity indices, showed the presence of two associations: one consisting of hauls carried out at depths of 250-500 m, where Sepietta oweniana, Todaropsis eblanae and Loligo forbesi were most frequently caught, and another comprising deeper hauls (up to $800 \mathrm{~m}$ depth) characterized by typical species of the slope, such as, Pteroctopus tetracirrhus, Neorossia caroli, Todarodes sagittatus and Abralia veranyi.

The number of cephalopod species and the hourly yield decreased with depth and varied with season. The highest mean cephalopod catches per hour $(>6 \mathrm{~kg} / \mathrm{hr})$ were observed in the depth zone 250-500 m in September 1999 and 2000, resulting in a higher percentage (5\%) of cephalopods in the total catch. Of the cephalopod species collected, Loligo forbesi, and of the ommastrephid squids, Todaropsis eblanae, Todarodes sagittatus and Illex coindetii, were of commercial interest.

Keywords: cephalopods, deep-water trawl surveys, Loligo forbesi, Mediterranean Sea, Ommastrephidae.

\section{Introduction}

The Ionian Sea is a deep-water basin in the Central Mediterranean Sea. The fleets of two countries, Italy and Greece, exploit the fishery resources in this area. Until recently commercial trawling in the eastern Ionian Sea was restricted to the continental shelf. In 1996, in the framework of a European Commission FAIR project for the investigation of fisheries resources in the deeper waters of the south-eastern Ionian Sea, the red shrimps Aristaeomorpha foliacea and Aristeus antennatus were found in commercial quantities (Petrakis, MS
1998). Following this an inter-regional project called "Interregional environmental studies in the Ionian Sea" (INTERREG II) was undertaken in 1999 to assess the extent of the resources of red shrimps, commercial fish and cephalopod species over a wider area of the Northeastern Ionian slope.

Several studies on the biogeography of cephalopods in the Mediterranean Sea have shown a good representation of cephalopods on the upper and middle slope (200-800 m) (Bonnet, 1973; Mangold, 1973; Bello, 1985; Sanchez, 1986; Tursi and D'Onghia, 1992; Belcari and Sartor, 1993; Villanueva, 
1992; Gonzalez et al., 1998; Quetlas et al., 2000). However, information on the quantitative composition of cephalopod catches deeper than $500 \mathrm{~m}$ is very limited and is only for the western Mediterranean (Belcari and Sartor, 1993; Gonzalez et al., 1998; Quetlas et al., 2000).

In the present study, the faunal composition, abundance and bathymetric distribution of the cephalopods collected on the slope of the Northeastern Ionian Sea are described. In addition preliminary results on the population structure of the commercial squid species are presented.

\section{Materials and Methods}

The data for analysis were from 4 trawl surveys carried out on the slope of the Northeastern Ionian Sea $\left(39^{\circ} 54^{\prime} \mathrm{N}-37^{\circ} 57^{\prime} \mathrm{N}, 19^{\circ} 18^{\prime} \mathrm{E}-20^{\circ} 45^{\prime} \mathrm{E}\right)$ in September 1999, April, July and September 2000.The gear used for sampling was a bottom trawl. Both trawl nets used by the Greek and Italian commercial trawlers hired for these surveys, were constructed of nylon with
$20 \mathrm{~mm}$ (from knot to knot) mesh size in the cod end. The length of the trawl net and the bridles (ropes between otter board and net) used by the Greek trawler were 44 and $218 \mathrm{~m}$ respectively, whereas those of the Italian trawler were 56.6 and $225 \mathrm{~m}$. A total of 146 hauls of one hour duration were performed during daytime at 54 stations between 257 and $1212 \mathrm{~m}$ depth (Fig. 1).

Numbers of individuals and total weight by species were recorded on board together with the haul data (date, location, duration, depth). Cephalopod species were identified using a key for the Mediterranean (Mangold and Boletzky, 1987). The mantle length (ML) was measured to the nearest $\mathrm{mm}$. Sex, maturity and individual weight were recorded for commercial squid species.

To detect species zonation patterns by depth, the data of the April 2000 survey were utilized, during which more hauls were distributed in the different depth strata in proportion to their area. The data matrices, comprising the numbers of individuals and

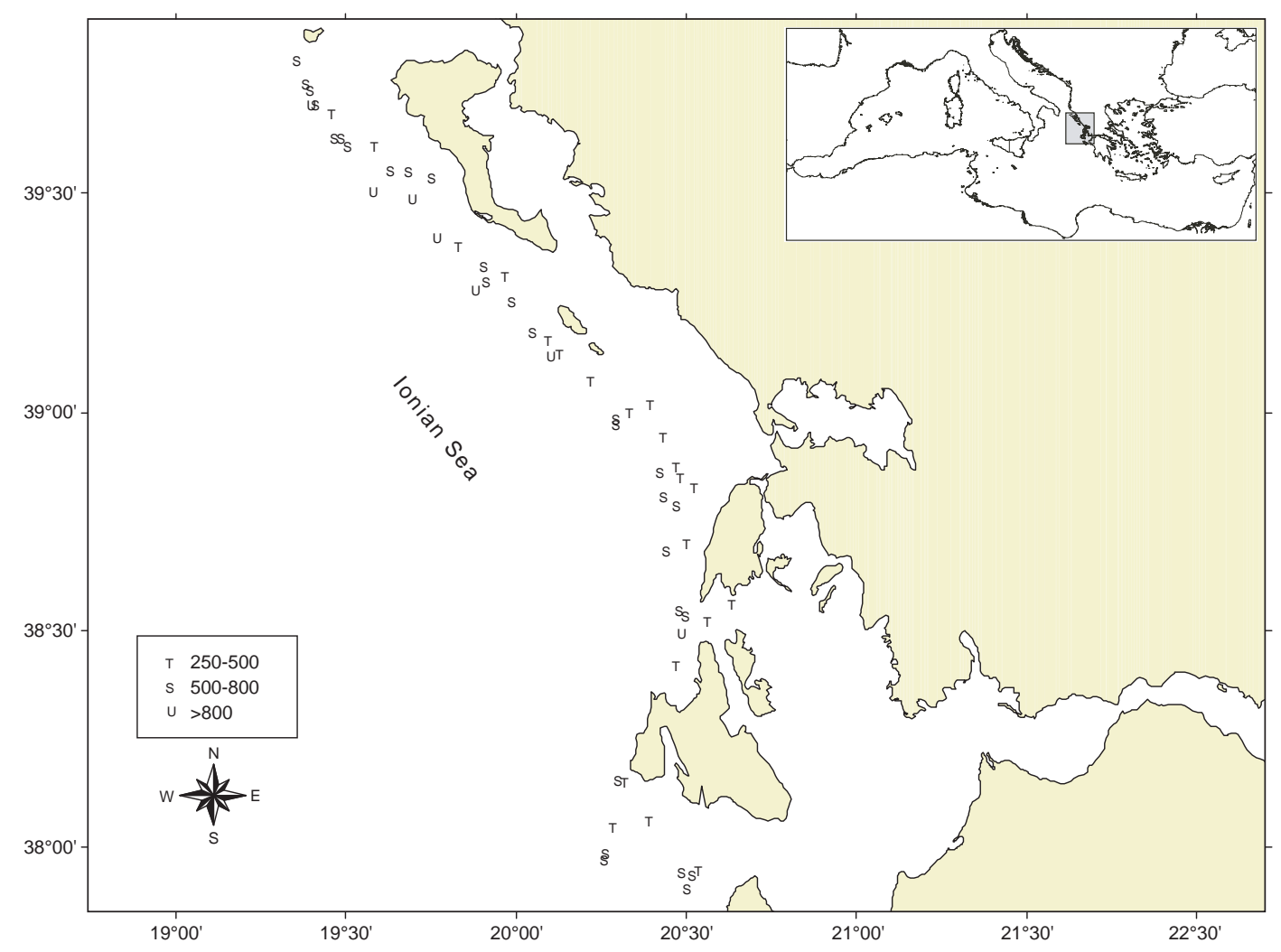

Fig. 1. Map of the Northeastern Ionian Sea (central Mediterranean) showing the location of the sampling stations by depth zone, during the surveys of INTERREG carried out from September 1999 to September 2000 . 
weights per hour of trawling of each species and station, were $\log (x+1)$ transformed and the haulsimilarity percentage was calculated using the BrayCurtis coefficient (Bray and Curtis, 1957) by the PRIMER-v5 software (Clarke and Gorley, 2001). Subsequently the similarity matrices were subjected to both clustering (employing group-average linking) and ordination (employing non-metric multidimensional scaling, MDS) (Clarke and Warwick, 1994). The results of the cluster analysis were displayed in the form of dendrogram and those of MDS as two-dimensional map of stations in different depth zones. Species that appeared only once in these surveys were omitted from the analysis, as well as, hauls in which only one cephalopod species was found. The SIMPER (similarity percentages) routine (Clarke, 1993) was applied to identify which species account for most of the similarity within each group resulting from the cluster analysis and which ones contribute most to the dissimilarity between groups. All subsequent analyses were made using the groups resulting from the cluster analysis.

To assess the commercial potential of cephalopods, the mean cephalopod catch per hour and its percentage contribution to the total catch as well as the mean CPUE ( $\mathrm{g} / \mathrm{hr}$ ) by species were calculated per depth zone and survey.

\section{Results}

\section{Cephalopod fauna and assemblages}

A total of 25 species of cephalopods were identified, including 10 oegopsid squids, two myopsid squids, five octopods, two cuttlefishes and six sepiolids (Table 1). Remains of female shells of Argonauta argo were also recorded, but since no entire individuals were caught, the species was not taken into account in this study. The most common cephalopod caught was Sepietta oweniana, followed by Todaropsis eblanae, Illex coindetii and Loligo forbesi. The pelagic squids Ctenopteryx sicula, Galiteuthis armata and the octopod Octopus vulgaris, usually inhabiting shallower waters, were collected only on one occasion.

The dendograms of similarities (Fig. 2A, C) revealed the existence of two main groups: one corresponding to hauls in the shallower stratum 250$500 \mathrm{~m}$ and another with hauls carried out at depths from 500 to $800 \mathrm{~m}$. The results of the ordinations (MDS) agree with the above pattern (Fig. 2B, D). Although some species were present in both groups, species composition and catch rates characterized, to some extent, the different faunal assemblages, and distinguished them from each other. Sepietta oweniana, Todaropsis eblanae and Loligo forbesi were found to contribute most to the similarity within the group of shallower hauls, as well as to the differentiation of the two groups, according to the SIMPER analysis. Pteroctopus tetracirrhus was the main indicator species for the group of deeper hauls.

\section{Catch composition and commercial potential}

Cephalopods were present in 94 hauls (48 stations) of the total of 146 valid hauls (54 stations). The frequency of occurrence of cephalopods in the catches decreased with depth (Table 2). In waters deeper than $800 \mathrm{~m}$ only 10 species were reported and the number of individuals was generally low. The total cephalopod catch per hour did not exceed $0.1 \mathrm{~kg}$ in any season. The highest values of the mean cephalopod catch per hour were observed in September in the 250$500 \mathrm{~m}$ depth zone, resulting also in higher percentages of cephalopods in the total catch.

The species composition of the catch of cephalopods, varied considerably both by depth and season (Table 3). Most of the frequently caught species ( $>5 \%$ of hauls) had higher CPUE values in the shallower depth zone and only Neorossia caroli and Abralia veranyi were caught more frequently and in greater quantities in the 500-800 m depth zone. Loligo forbesi together with ommastrephid squids, T. sagittatus, T. eblanae and I. coindetii, constituted the major part $(>60 \%)$ of cephalopod catches in the 250-500 $\mathrm{m}$ depth zone, their contribution reaching $90 \%$ during autumn cruises. Loligo forbesi dominated the cephalopod catches in the depth zone $250-500 \mathrm{~m}$ during summer and autumn cruises, when it also appeared among the three most abundant species in deeper waters. Among the two short-finned squids, the proportion of $I$. coindetii was higher in autumn of both years whereas $T$. eblanae was more abundant in spring. The insufficient sampling of the $250-500 \mathrm{~m}$ depth zone during the two last cruises has most probably resulted in their low catches. T. sagittatus was the most abundant ommastrephid in terms of biomass during the summer and autumn cruises at depths 500-800 $\mathrm{m}$, but disappeared from the catches in the spring.

\section{Seasonal composition of commercial squid catches}

Loligo forbesi. The catches consisted almost exclusively of immature individuals. The ML range was $45-240 \mathrm{~mm}$ and $42-400 \mathrm{~mm}$ for females and males, respectively. The length frequency distributions of females revealed the presence of at least two cohorts in the catches with ML ranges 45-120 $\mathrm{mm}$ and 


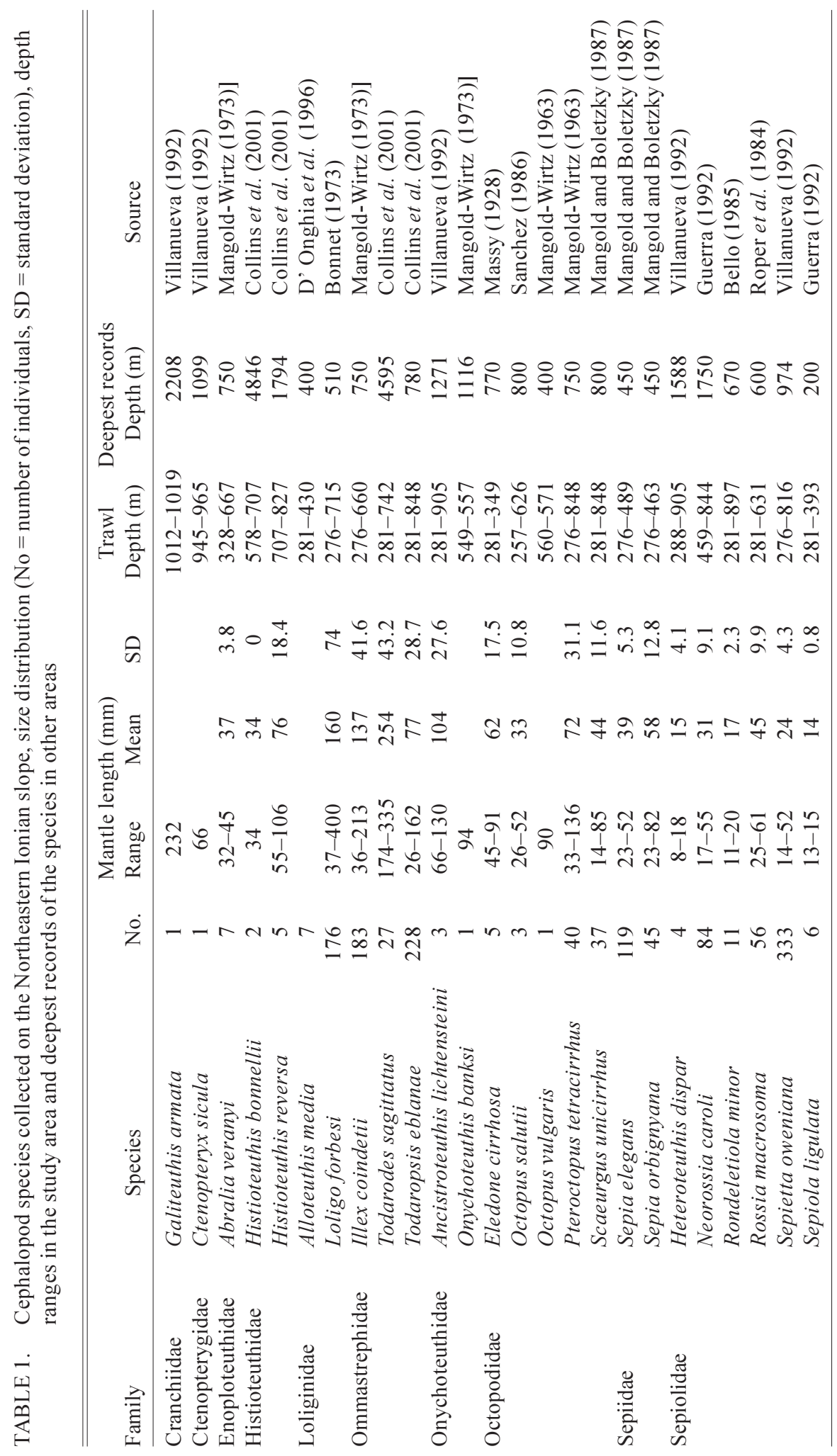




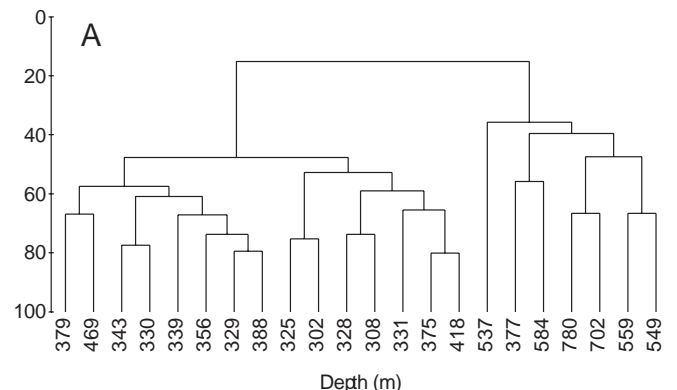

Deph (m)

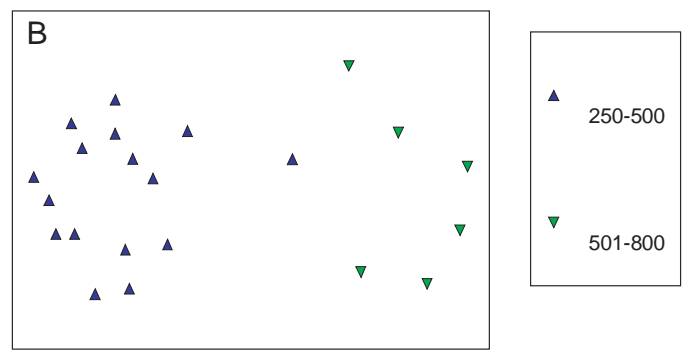

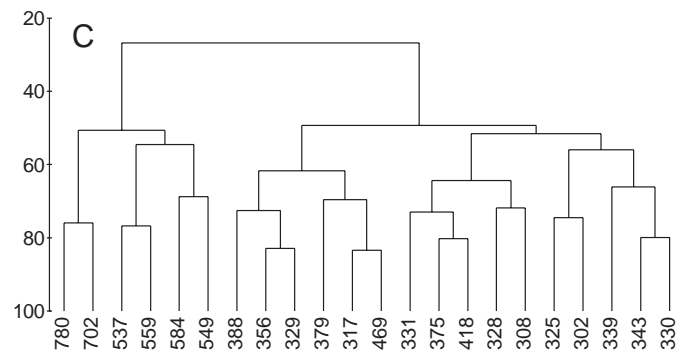

Deph (m)

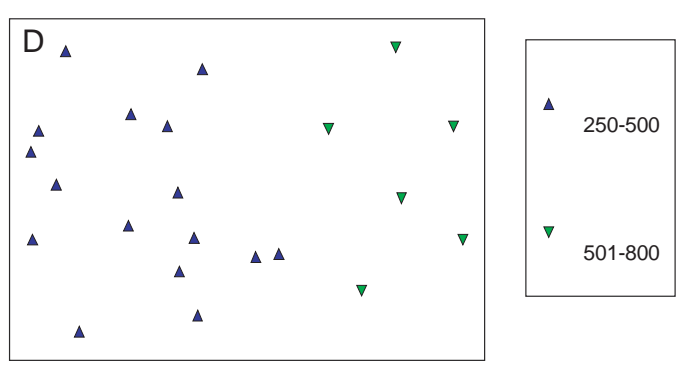

Fig. 2. Clustering dendrograms and multidimensional scaling (MDS) ordinations of the hauls performed during the survey of April 2000 on the slope of the Northeastern Ionian Sea, using group-average linking of Bray Curtis similarities calculated on $\log (x+1)$ transformed $(\mathbf{A}, \mathbf{B})$ numbers of individuals and $(\mathbf{C}, \mathbf{D})$ weights of cephalopod species caught per fishing hour.

TABLE 2. Cephalopod frequency of occurrence (f number of hauls in which each species was caught in relation to the number of hauls taken), average catch per unit of fishing effort $(\mathrm{kg} / \mathrm{hr})$ and percentage contribution (c) in the total catch weight per depth zone and survey during exploratory trawling on the Northeastern Ionian slope.

\begin{tabular}{lccccc}
\hline \hline Survey & Depth & $\begin{array}{l}\text { No. } \\
\text { of hauls }\end{array}$ & $\begin{array}{c}\text { f } \\
(\%)\end{array}$ & $\begin{array}{c}\text { Cephalopods } \\
\mathrm{kg} / \mathrm{hr}\end{array}$ & $\begin{array}{c}\mathrm{c} \\
\mathbf{( \% )}\end{array}$ \\
\hline \multirow{4}{*}{ September 1999 } & $250-500$ & 19 & 100 & 6.8 & 5 \\
& $501-800$ & 7 & 86 & 1.2 & 2 \\
& $>800$ & 6 & 50 & $<0.05$ & $<0.1$ \\
April 2000 & $250-500$ & 16 & 100 & 2.2 & 3 \\
& $501-800$ & 28 & 29 & 0.1 & 1 \\
& $>800$ & 6 & 0 & & \\
July 2000 & $250-500$ & 7 & 86 & 3.1 & 2 \\
& $501-800$ & 24 & 62 & 0.2 & 1 \\
& $>800$ & 4 & 25 & $<0.05$ & $<0.1$ \\
September 2000 & $501-800$ & 2 & 100 & 10.2 & 5 \\
& $>800$ & 4 & 74 & 0.3 & 1 \\
\hline
\end{tabular}

140-230 mm. Small individuals (ML $<140 \mathrm{~mm}$ ) were present during all four surveys but their percentage was relatively higher in September 1999.
Todarodes sagittatus. Few, but relatively large individuals (ML: 174-335 mm) were caught. The samples examined consisted mainly of immature 
females and mature males, with a sex ratio in favor of females ( 28 females, 17 males).

Todaropsis eblanae. The ML ranged from 26 to $162 \mathrm{~mm}$. Recruits (ML: 26-70 mm) were found during all cruises, representing the major part of the population in September 1999. Males were observed to attain maturity earlier than females and at a smaller size, as commonly observed in ommastrephids.

Illex coindetii. This species was caught during all surveys in the 250 to $500 \mathrm{~m}$ depth zone. A small number of large individuals (ML: 150-213 mm) were caught in deeper waters only in the autumn surveys. The ML ranged from $36 \mathrm{~mm}$ (July 2000) to $213 \mathrm{~mm}$ (September 2000). The length distribution was bimodal in autumn 1999, with ML ranges of 50-110 $\mathrm{mm}$ and 120-190 mm. In April 2000 only the group of larger individuals (ML: 120-190 mm) was present in the catches, whereas, in July 2000 only two unsexed juveniles (ML: 36-49 mm) were found.

\section{Discussion}

A total of 32 cephalopod species have been recorded from the eastern Ionian Sea, including Atlanto-Mediterranean species and some cosmopolitan ones (Degner, 1926; Kaspiris and Tsiambaos, 1984, 1986; unpublished data from the International Bottom Trawl Surveys in the Mediterranean Sea 199699). Deep-water trawling yielded some uncommon species such as Ancistroteuthis lichtensteini, Ctenopteryx sicula and Galiteuthis armata, which were recorded for the first time in the eastern Ionian Sea, extending the cephalopod fauna of this area to 35 species. Other species which are known to inhabit the slope areas of the central Mediterranean Sea, such as Abralia pfefferi, Ancistrocheirus lesueurii, Bathypolypous sponsalis, Brachioteuthis riisei, Chiroteuthis veranyi, Pyroteuthis margaritifera, Octopoteuthis sicula ( Degner, 1926; Kaspiris and Tsiambaos, 1984, 1986; Jereb and Ragonese, 1994; D'Onghia et al., 1995, 1997, 1998; Maiorano et al., 1999) were absent from the catches in the present surveys. Most of these species, with the exception of B. sponsalis, which has never been found in the Ionian Sea (D'Onghia et al., 1993), are mesopelagic and they are preferentially captured by trawls with a wide horizontal and vertical opening as shown during comparative trawling in the western Ionian Sea (Maiorano et al., 1999). All the species recorded in the present study are also known from the Northeastern Atlantic (Guerra, 1984; Mangold and Boletzky, 1988), however, some of them, like
S. ligulata, O. salutii, P. tetracirrhus and S. unicirrhus are restricted to the subtropical zone, confirming the invasion of the Mediterranean by tropical fauna from the Atlantic (Mangold and Boletzky, 1988). Other nectonic and benthic species like L. forbesi, $O$. vulgaris and $R$. minor, occuring over the shelf in the temperate part of their distributional range (Robson, 1929; Guerra, 1982; Collins et al., 2001) are found deeper in the warmer waters of the Mediterranean Sea and in subtropical Atlantic areas (Roper et al., 1984; Bello, 1985; Quetglas et al., 2000; Mastrototaro and Lefkaditou, 2001), indicating that their preference for higher temperatures could be considered as a factor controlling their depth range. On the contrary, mesopelagic incirrate octopods, considered true cold water species and found to dominate cephalopod catches on the middle slope of the north-east Atlantic (Collins et al., 2001), were absent from our catches as previously noted for the Mediterranean Sea (Mangold and Boletzky, 1988).

Deep-water trawling contributed to substantial extensions of depth ranges in the loliginid squid L. forbesi two octopod species (O. vulgaris, $P$. tetracirrhus) and two sepiolids (S. ligulata, $R$. minor) (Table 1), that could be related to the relatively higher water temperatures in the eastern Ionian Sea than in the western most areas (Brasseur et al., 1996), where deepest records of these species were previously reported.

The separation of species assemblages by depth gradient in the study area is similar to that found in other areas of the Mediterranean Sea. The highest abundance levels of Sepietta oweniana, Todaropsis eblanae, Loligo forbesi, Pteroctopus tetracirrhus and Illex coindetii have usually been recorded near to the shelf break area (Mangold-Wirtz, 1963; Lumare, 1970; Mangold and Boletzky, 1988; D'Onghia et al., 1996; Sanchez et al., 1998). Neorossia caroli is a typical bathybenthic species in the Mediterranean relatively more abundant at depths greater than $400 \mathrm{~m}$ (Mangold-Wirtz, 1963; Lumare, 1970; Villanueva, 1992; D'Onghia et al., 1993) found on muddy bottoms together with Todarodes sagittatus, Pteroctopus tetracirrhus and Bathypolypous sponsalis. Todarodes sagittatus is a species characterized by broad vertical distribution occurring in coastal bank areas of 80 $200 \mathrm{~m}$ depth (Wiborg and Gjøsæter, MS 1981) and down to $4595 \mathrm{~m}$ (Collins et al., 2001). In the Mediterranean it has been found from 100 to $800 \mathrm{~m}$ and the greatest frequency of individuals appeared deeper than $400 \mathrm{~m}$ (Mangold-Wirtz, 1963; Quetglas et al., 1998). 
LEFKADITOU et al.: Cephalopod Species in Ionian Sea

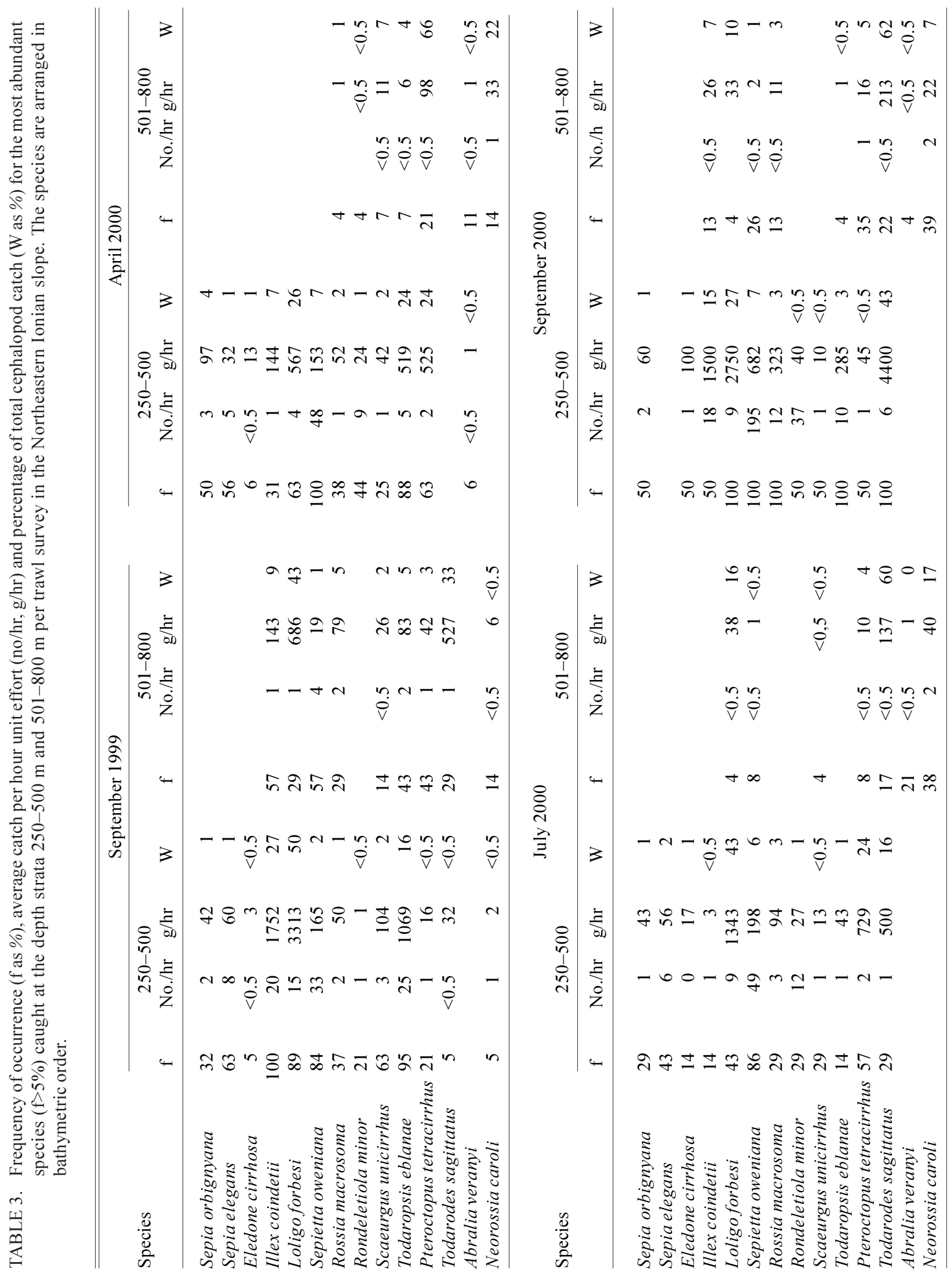


Cephalopods represented, on average, $2.2 \%$ of the total catch during all surveys carried out from September 1999 to September 2000 in the Northeastern Ionian slope. The highest hourly yields, though with high variability, were obtained at depths of 250 $500 \mathrm{~m}$ and were generally higher than those observed at these depths in the western and southeastern Ionian Sea (Tursi and D'Onghia, 1992; Petrakis, MS 1998), the eastern Aegean Sea (Salman et al., 1997) or in areas of the western Mediterranean (Belcari and Sartor, 1993; Gonzalez et al., 1998; Sartor et al, 1998; Quetglas et al., 2000).

Considering the quantity of the species in hauls, their edibility and the existence of a market for the species in Europe, about $90 \%$ of the cephalopod catch fished down to depths of $800 \mathrm{~m}$ is marketable. Among the species frequently collected, only the octopod P. tetracirrhus is of no interest for human consumption due to its gelatinous flesh. About $10 \%$ of cephalopod catch consists of sepiolids, small sized cuttlefishes and octopods (Table 3 ) of low or no commercial value, whereas Loligo forbesi and the ommastrephid squids (Todaropsis eblanae, Todarodes sagittatus and Illex coindetii) compose the greatest part $(\sim 80 \%)$. These species, except $I$. coindetii, do not frequently appear in trawl catches from Greek waters (D'Onghia et al., 1996; Lefkaditou and Papaconstantinou, 1999) or from other areas in the Mediterranean Sea (MangoldWirtz, 1963) and consequently very little is known on their biology and dynamics in this area.

Loligo forbesi has been shown to have an extended spawning season in the Atlantic (Martins, 1982; Martins and Porteiro, 1988; Lum-Kong et al., 1992; Pierce et al., 1994; Collins et al., 1995), with mature individuals less frequent in late summer and autumn (Lum-Kong et al., 1992; Porteiro and Martins, 1994). In the central Mediterranean the maximum occurrence of mature individuals of both sexes in trawl catches has been observed in winter (Ragonese and Jereb, 1986), a fact that could explain the lack of mature individuals in our samples. The occurrence of mature females of T. eblanae in April probably indicates a peak of spawning in late spring as also suggested for this species in the eastern Atlantic (Gonzalez et al., 1994; Hernandez-Garcia and Castro, MS 1995). The low number of specimens caught in July and September of 2000 is due to the decrease in the number of hauls in the $250-500 \mathrm{~m}$ depth zone where this species is mainly distributed (Table 3). A future sampling programme focusing mainly at the shelf-break zone could provide useful information on this species in the Ionian Sea, where it seems to be quite abundant. T. sagittatus although frequently caught during the summer and autumn surveys, never exceeded 10 individuals per haul. As stated by other authors this species seems to live in small groups (Quetglas et al., 1998) and at times some distance from the bottom (Moiseev, 1991) so that bottom trawl may not be the most appropriate gear for its exploitation (Lordan et al., 2001).

\section{References}

BELCARI, P., and P. SARTOR. 1993. Bottom trawling teuthofauna of the northern Tyrrhenian Sea. Sci. Mar., 57: $145-152$.

BELLO, G. 1985. Su una raccolta di Cefalopodi pescati nel mesobatiale del Golfo di Taranto. Boll. Malacol., 21: $275-280$.

BONNET, M. 1973. Les céphalopodes capturis par la "Thalassa" en Novembre 1969 au large de la Libye et la cote orientale Tunisienne. Rev. Trav. Inst. Pêches Marit., 37 (2): 253-256.

BRASSEUR, P., J. M. BRANKART, R. SCHOENAUER and J.M. BECKERS, 1996. Seasonal temperature and salinity fields in the Mediterranean sea: climatological analyses of an historical data set. Deep-sea Res., 43: 159-192.

BRAY, J. R., and J. T. CURTIS. 1957. An ordination of the upland forest communities of Southern Wisconsin. Ecol. Monogr., 27: 325-349.

CLARKE, K. R. 1993. Non-parametric multivariate analyses of changes in community structure. Austr. J. Ecol., 18: $117-143$.

CLARKE, K. R., and R. M. WARWICK. 1994. Change in marine communities: an approach to statistical analysis and interpretation. Plymouth Marine Laboratory, Plymouth, U.K., 144 p.

CLARKE, K. R., and R. N. GORLEY. 2001. PRIMER v5: User Manual/Tutorial. PRIMER-E Ltd, Plymouth, U.K., $91 \mathrm{p}$.

COLlinS, M. A., G. M. BURNELL, and P. G. RODHOUSE. 1995. Recruitment, maturation, and spawning of Loligo forbesi (Cephalopoda: Loliginidae) in Irish waters. ICES J. Mar. Sci., 52: 127-137.

COllins, M. A., C. YAU, L. AllCOCK, and M. H. THURSTON. 2001. Distribution of deep-water benthic and bentho-pelagic cephalopods from the north-east Atlantic. J. Mar. Biol. Ass. U.K., 81: 105-117.

DEGNER, E. 1926. Cephalopoda. Report on the Danish Oceanographic Expeditions 1908-10 to the Mediterranean and adjacent seas, 9: Vol. II. Biology, C.1. p. 1-94.

D'ONGHIA, G., A. TURSI, P. PANETTA, and A. MATARRESE. 1993. Occurrence of Neorossia caroli (Joubin, 1902) (Mollusca: Cephalopoda) in the middle-eastern Mediterranean Sea. In: Recent advances in fisheries biology. Contributed papers to 1991 CIAC international symposium on recent advances in cephalopod fisheries biology. Tokai University Press, Tokyo, p. 93-96.

D'ONGHIA, G., P. MAIORANO, and P. PANETTA. 1995. 
Octopoteuthis sicula (Ruppel, 1844) and Brachioteuthis riisei (Steenstrup, 1882) (Cephalopoda: Teuthoidea) from the north-western Ionian Sea. Boll. Malacologico, 31: 137-142.

D'ONGHIA, G., A. MATARRESE, A.TURSi, and P. MAIORANO. 1996. Cephalopods collected by bottom trawling in the North Aegean Sea (Eastern Mediterranean). Oebalia, 22: 33-46.

D'ONGHIA, G., P. MAIORANO, and A. TURSI. 1997. Morphometric and biological data on Ancistrocheirus lesueurii (Orbigny, 1842) from the middle-eastern Mediterranean Sea. Sci. Mar., 61: 389-396.

D'ONGHIA, G., P. MAIORANO, M. PANZA, and P. PANETTA. 1998. Occurrence of Chtenopteryx sicula (Veran, 1851) (Mollusca, Cephalopoda) in the northwestern Ionian Sea. Biol. Mar. Medit., 5: 690-693.

GONZALEZ, A. F., M. RASERO, and A. GUERRA. 1994. Preliminary study of Illex coindetii and Todaropsis eblanae (Cephalopoda: Ommastrephidae) in northern Spanish Atlantic waters. Fish Res., 21: 115-126.

GONZALEZ, M., P. TORRES, and L. GIL DE SOLA. 1998. Preliminary data on the bathymetric distribution of cephalopods in the northern Alboran Sea. Rapp. Comm. Int. Mer Médit., 35: 444-445.

GUERRA, A. 1982. Rondeletiola minor (Naef, 1912) (Cephalopoda: Sepioidea), new record for the Central East Atlantic. The Veliger, 24: 300-301.

1984. Cephalopods of the Ria de Vigo (NW of Spain). Preliminary results. Proceedings of the first seminar on Marine Sciences: The Galician "Rias", Vigo, March 1983, Cuad. Area cienc. Mar. Semin. Estud. Galegos, 1: 333-348 (in Spanish).

1992. Mollusca, Cephalopoda. In: Fauna Iberica. Ramos, M.A. et al., eds., Vol. I, Museo Nacional de Ciencias Naturales. CSIC, Madrid, 327 p.

HERNANDEZ-GARCIA, V., and J. J. CASTRO. MS 1995. Reproductive biology of the subfamily Ilicinae, Illex coindetii and Todaropsis eblanae (Cephalopoda: Ommastrephidae Steenstrup, 1857) off Northwest Africa. ICES C.M. Doc., No. K:17, 10 p.

JEREB, P., and S. RAGONESE. 1994. The Mediterranean teuthofauna: towards a biogeographical coverage by regional census. II: Strait of Sicily. Boll. Malacologico, 30: $161-172$.

KASPIRIS, P., and P. TSIAMBAOS. 1984. Some uncommon cephalopods from western Korinthiakos Gulf (MolluscaDibranchiata). Biljeske Notes, 62: 1-4.

1986. A preliminary list of cephalopoda from western Greece. Biologia Gallo-hellenica, 12, p. 209.

LEFKADITOU, E., and C. PAPACONSTANTINOU. 1999. Cephalopod distribution and fisheries in the Thracian Sea. In: Proceedings of the workshop of the Geotechnical Chamber of Greece - Branch of Thrace on the management of fish stocks in the Thracian Sea, Alexandroupolis, Greece, May 1999, p. 15-32 (in Greek).

LORDAN, C., M. A. COLlinS, N. L. KEY, and E. D. BROWNE. 2001. The biology of the ommastrephid squid, Todarodes sagittatus, in the north-east Atlantic. J. Mar. Biol. Ass. U.K., 81: 299-306.
LUMARE, F. 1970. Nota sulla distribuzione di alcuni cefalopodi del Mar Tirreno. Boll. Pesca Piscic. Idrobiol., 25: 313-344.

LUM-KONG, A., PIERCE G. J., and C. YAU. 1992. Timing of spawning and recruitment in Loligo forbesi (Cephalopoda: Loliginidae) in Scottish waters. J. Mar. Biol. Ass. U.K., 72: 301-311.

MAIORANO, P., F. MASTROTOTARO, F. CASAMASSIMA, and P. PANETTA. 1999. Comparative analysis of teuthofauna caught by two different trawl nets. Biol. Mar. Medit., 6: 579-583.

MANGOLD-WIRTZ, K. 1963. Biologie des Cephalopodes benthiques et nectoniques de la Mer Catalane. Vie Millieu, Supl., 13, 285 p.

MANGOLD, K. 1973. Les Céphalopodes récoltés en Méditerrantéé par le "Jean-Charcot". Campagnes Polymède I et II. Rev. Trav. Inst. Peches Marit., 37(3): 391-395.

MANGOLD-WIRTZ, K. 1973. La faune teuthologique actuelle Méditerranèe et ses rapports avec les mers voisines. Rapp. Comm. Int. Mer Médit., 21: 779-782.

MANGOLD, K., and S. V. BOLETZKY. 1987. Céphalopodes. In: Fiches d' identification des especes pour les besoins de la pêche. W. Fischer, M. L. Bauchot and M. Schneider (eds), (Revision 1) Méditerranèe et Mer Noire, 1: 633-714.

1988. Mediterranean cephalopod fauna. In: The Mollusca 12: Paleontology and neontology of cephalopods. M. R. Clarke and E. R. Trueman (eds), Academic Press, p. 315-330.

MARTINS, H. R., 1982. Biological studies of the exploited stock of Loligo forbesi Steenstrup 1986 (Mollusca: Cephalopoda) in the Azores. J. Mar. Biol. Assoc. U.K., 62: 799-808.

MARTINS, H. R., and F. M. PORTEIRO. MS 1988. The exploited stock of Loligo forbesi in the Azores: Additional notes on the biology and fisheries. ICES C.M. Doc., K:8, $7 \mathrm{p}$.

MASSY, A. 1928. The Cephalopoda of the Irish Coast. Proc. Roy. Sci. Acad., 38B(2): 25-37.

MASTROTOTARO, F., and E. LEFKADITOU. 2001. The occurrence of Octopus vulgaris Cuvier, 1797 on the bathial grounds of the eastern Ionian Sea. Rapp. Comm. Int. Mer Médit., 36, $300 \mathrm{p}$.

MOISEEV, S.I. 1991. Observation of the vertical distribution and behavior of nektonic squids using manned submersibles. Bull. Mar. Sci., 49: 446-456.

PETRAKIS, G. MS 1998. Catch per unit of effort fluctuations, in deep waters in west coast of Greece (Ionian Sea) ICES C.M. Doc., M:44, 9 p.

PIERCE, G. J., P. R. BOYLE, L. C. HASTIE, and A. M. SHANKS. 1994. Distribution and abundance of the fished population of Loligo forbesi in the United Kingdom waters: analysis of fishery data. Fish. Res., 21: 193-216.

PORTEIRO, F. M., and H. R. MARTINS. 1994. Biology of Loligo forbesi Steenstrup 1986 (Mollusca: Cephalopoda) in the Azores: sample composition and maturation of squid caught by jigging. Fish. Res., 21: 103-114. 
Quetglas, A., F. AlEMANY, A. CARBONELL, P. MERELLA, and P. SANCHEZ. 1998. Some aspects of the biology of Todarodes sagittatus (Cephalopoda: Ommastrephidae) from the Balearic Sea (Western Mediterranean). Sci. Mar., 62: 73-82.

QUETGLAS, A., A. CARBONELL, and P. SANCHEZ., 2000. Demersal Continental Shelf and Upper Slope Cephalopod Assemblages from the Balearic Sea (North-Western Mediterranean). Biological Aspects of Some Deep-Sea Species. Estuar. Coast. Shelf Sci., 50(6): 739-749.

RAGONESE, S., and P. JEREB. 1986. L. forbesi Steenstrup 1986 (Cephalopoda: Loliginidae) nel versante Siciliano del mare pelagico (Canale di Sicilia): Nota preliminare sulla distribuzione, compozizione per taglia e biologia riprodutiva. Nova Thalassia, 8: 529-555.

ROBSON, G. C. 1929. A monograph of recent Cephalopoda. Part I. Octopodinae. British museum (Natural history). London, $236 \mathrm{p}$.

ROPER, C. F. E., M. J. SWEENEY, and E. NAUEN. 1984. FAO species Catalogue. Vol. 3 - Cephalopods of the world. An annotated and illustrated catalogue of species of interest to fisheries. FAO Fish. Syn., 125(3), 277 p.

SALMAN, A., T. KATAGAN, and H.A.BENLI. 1997. Bottom trawl teuthofauna of the Aegean Sea. Arch. Fish. Mar. Res., 45(2): 183-196.
SANCHEZ, P. 1986. Distribución batimétrica y abundancia de algunos cefalópodos del mar Catalan. Invest. Pesq. 50: 237-246.

SANCHEZ, P., P. BELCARI, and P. SARTOR. 1998. Composition and spatial distribution of cephalopods in two north-western Mediterranean areas. In: Cephalopod Biodiversity, Ecology and Evolution. A. I. L. Payne, M. R. Lipinski, M. R. Clarke and M. A. C. Roeleveld (eds), S. Afr. J. Mar. Sci., 20: 17-24.

SARTOR, P., P. BELCARI, A. CARBONELL, M. GONZALEZ, A. QUETGLAS, and P. SANCHEZ . 1998. The importance of cephalopods to trawl fisheries in the western Mediterranean. In: Cephalopod Biodiversity, Ecology and Evolution. A. I. L. Payne, M. R. Lipinski, M. R. Clarke and M. A. C. Roeleveld (eds), S. Afr. J. Mar. Sci., 20: 67-72.

TURSI, A., and G. D'ONGHIA. 1992. Cephalopods of the Ionian Sea (Mediterranean Sea). Oebalia, 18: 25-43.

VILLANUEVA, R. 1992. Deep-sea cephalopods of the northwestern Mediterranean: indications of up-slope ontogenetic migration in two bathybenthic species. J. Zool., Lond., 227: 267-276.

WIBORG, K. F., and J. GJØSÆTER. MS 1981. The squid Todarodes sagittatus (Lamarck). Distribution and biology in Northern waters, August 1981-April 1982. ICES C.M. Doc., K:14, 18 p. 